\title{
Review Article on The World Economy: A Millennial Perspective by Angus Maddison
}

\author{
Andrew Sharpe \\ Centre for the Study of Living Standards
}

A ngus Maddison's new book The World Economy: A Millennial Perspective ${ }^{1}$ provides an amazingly rich and comprehensive overview of world economic history. The volume updates and expands upon his wellknown earlier work, including Chinese Economic Performance in the Long Run (OECD, 1998) and Monitoring the World Economy, 1820-1992 (OECD, 1995). In my view, the book establishes Maddison as the leading macro-economic historian of his generation.

The book is organized into three chapters and six appendices. The first chapter discusses the contours of world development, looking at the nature and welfare implications of population change and long-term trends in GDP per capita. The second and longest chapter looks at the impact of western development on the rest of the world from 1000 to 1950. Topics discussed include Europe's decline from the first to tenth century, Western Europe's recovery and forging ahead in the 1000-1500 period, the Venetian Republic, Portugal, the trading world of the Indian Ocean, China, Japan, and the Philippines, the Portuguese in Brazil, the Netherlands, Britain, and the impact of British expansion on America, Africa, and Asia. The third chapter examines the world economy in the second half of the 20th century, analyzing the economic performance of the advanced capitalist countries, resurgent Asia, the problem economies of East Asia, West Asia, Latin America, the former Soviet Union and Eastern Europe, and Africa. The extensive appendices provide invaluable information on world population, GDP, and GDP per capita $^{2}$ for all parts of the world for very long time periods. Indeed, the over 200 tables in the volume alone are worth the price of the book.

This article reviews a number of the key findings of the study. It examines the long-term evolution of the world leaders in GDP per capita; highlights new interpretations of economic history that come from Maddison's estimates of GDP per capita; outlines a number of interesting perspectives on the early economic history of the western hemisphere based on Maddison's population estimates; summarizes per capita GDP developments in the second half of the 20th century in the underdeveloped countries and developments in the 1990s in the transition economies; revisits trends in Canada's economic performance relative to that in the United States that emerge from Madison's new data; and discusses the relevance to current policymaking of some of Maddison's findings. 


\section{Chart 1}

\section{World Leaders in GDP per Capita, 1500-1998}

\section{0 international \$}

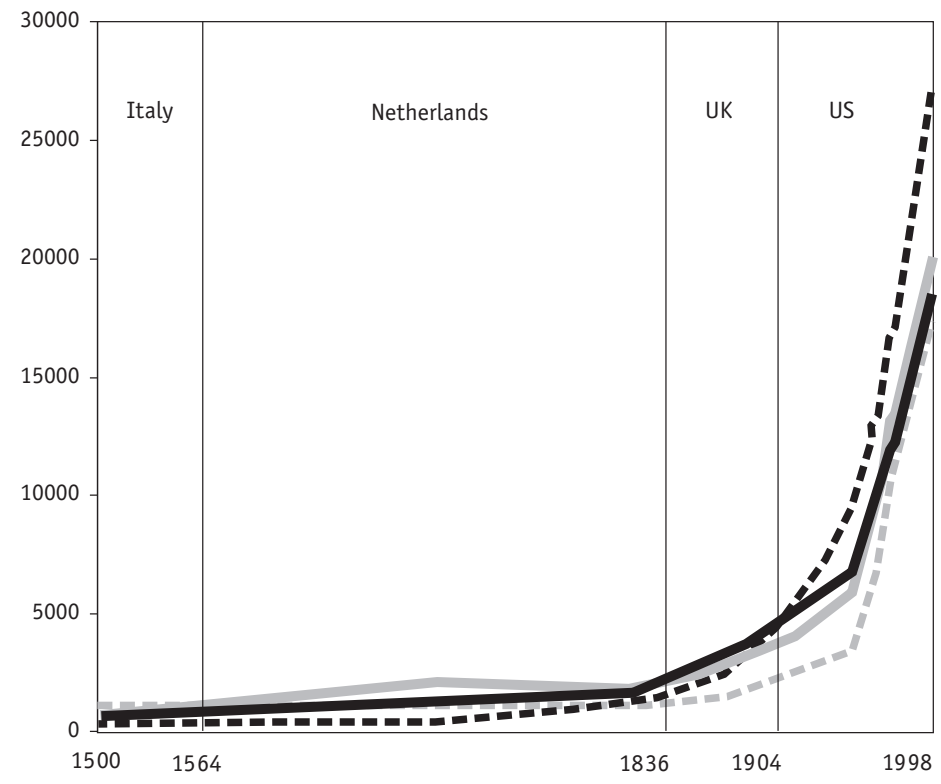

Real GDP per Capita (natural log)

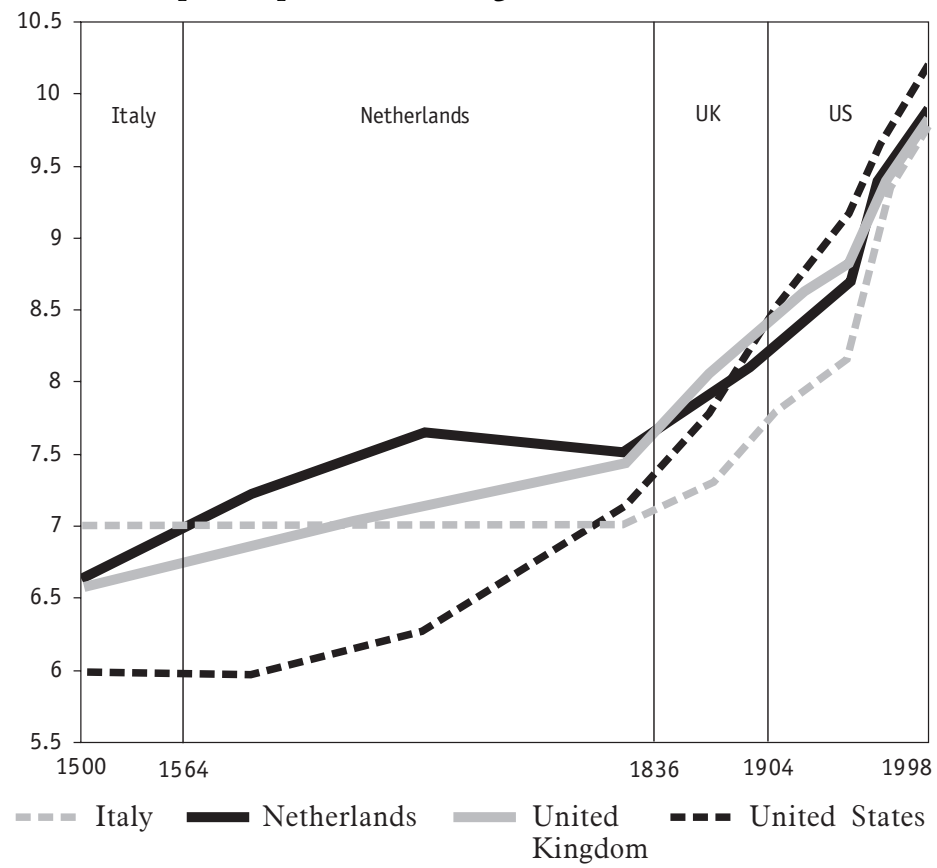

Note: Data are available for 1500,1600,1700, 1820, 1870, 1913, 1950, 1973 and 1998. Data for all other years are based on linear interpolation between years for which data are available. The graph shows the natural logarithm of GDP per capita in 1990 international \$. The actual values of GDP per capita can be calculated by taking the anti-log, that is, raising the natural base $e=2.718$ to the power of the natural logarithm.

Source: Maddison, Angus, The World Economy, A Millennial Perspective. OECD, 2001. Based on Table B-21, p. 264.

\section{The Quantification of World Economic History}

Maddison is a great believer in the quantification of economic history. He argues that it sharpens scholarly discussion, stimulates the development of rival hypotheses, and overall contributes to the dynamics of the research process. The key contribution of the volume to the literature is indeed Maddison's new comprehensive estimates of population, GDP and per capita GDP for the world economy over the past two millennia. He provides comparable estimates for literally all countries of the world for very long periods, going back to $0 \mathrm{AD}$ for all major regions, to 1000 for most major countries, and to 1950 for literally all countries of the world except the former Soviet Union and eastern Europe, which are covered from 1973 to $1998 .{ }^{3}$ These estimates are based on an extensive and meticulous use of primary and secondary sources, well documented in the volume.

Maddison's estimates of GDP per capita provide fascinating insights into the rise and fall of nations as world leaders in GDP per capita. His GDP per capita estimates back to 1500 allow the identification of world income leaders (Chart 1). During the first two thirds of the 16th century (and before) Italy was the richest country in the world, with a GDP per capita of \$1,100 (1990 international U.S. dollars), well above that of its closest rival, Britain (\$752). Around 1564, the Netherlands overtook Italy and remained the world leader until around 1836, a very long stretch. It in turn was replaced by the United Kingdom during the last two thirds of the 19th century. Around 1904, the United States replaced the United Kingdom as leader, a situation that still continues today.

Maddison estimates that GDP per capita in 1000 was lower in Western Europe (\$400 international dollars) than in Africa (\$416), Asia excluding Japan (\$450), and Japan (\$425). Indeed, 
Maddison estimates that Western Europe actually regressed during the first millennium, with per capita GDP down from $\$ 450$ in $0 \mathrm{AD}$.

Around 1500, Western Europe started to grow, while the other parts of the world stagnated. Maddison explains the exceptionalism of Western Europe's long-run economic performance, which has continued to this day, by the West's superior technological progress. These included the development of navigation, military technology, banking, accountancy, marine insurance, improvements in the quality of intellectual life with the development and spread of universities, and the introduction of the printing press.

With the divergence of growth paths, international inequality, as represented by the ratio of per capita GDP of the highest region to the lowest (Chart 2), has been on a more or less steady upward path. From a situation of virtual world income equality in 1000 (1.1:1), the inequality ratio by 1998 had reached 19:1. Only in the 1950-73 period when the per capita GDP growth in Asia excluding Japan (the region with the lowest per capita GDP) outpaced per capita growth in the western offshoots (the region with the highest GDP per capita) did the inequality ratio fall.

\section{New Interpretations of Economic History}

Maddison's new population and GDP estimates challenge conventional views of economic history in a number of areas. First, historians have traditionally seen 1500 as the pivotal break in growth performance when the pace of economic growth picked up in Western Europe and started to diverge from that in the rest of the world. Maddison argues that the divergence really started around 1100 with the start of the renaissance in Italy lead by Venice and was already quite wide by 1500 .

Second, historians equally have seen 1760 as the turning point in European economic history,

\section{Chart 2}

\section{International Spreads in GDP per Capita}

Ratio of Highest Region to Lowest Region

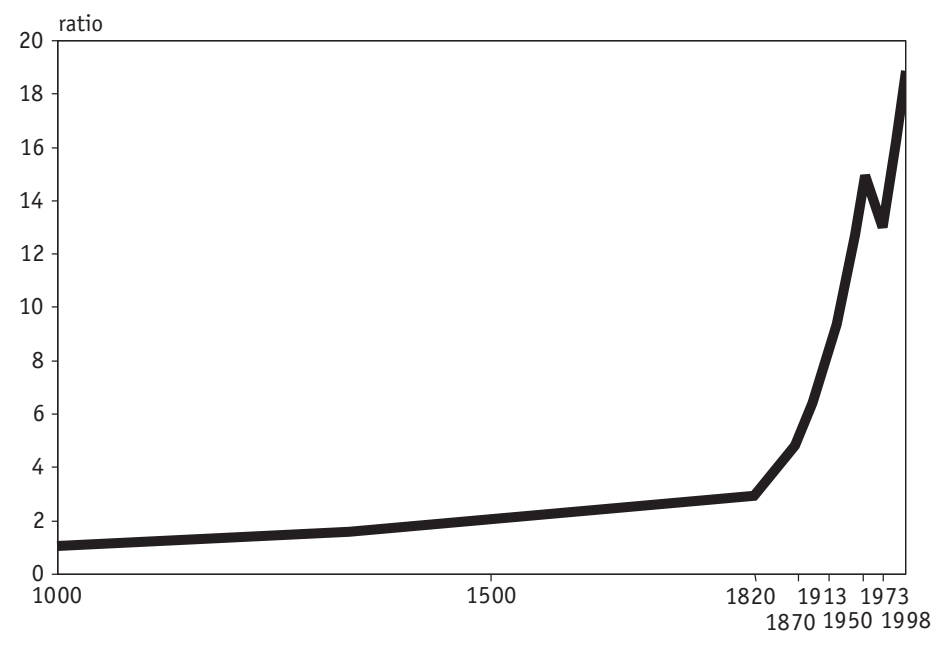

Note: Data are only available for 1000, 1500, 1820, 1870, 1913, 1950, 1973, and 1998. Data for all other years are based on linear interpolation between the years for which data are available. In 1000, Western Europe, Western Offshoots, Latin America, and Eastern Europe and Former USSR had the lowest GDP per capita, while Asia excluding Japan had the highest. In 1500, Africa and Western Offshoots had the lowest GDP per capita, while Western Europe had the highest. In 1820, Africa had the lowest, while Western Europe had the highest. In 1870, 1913, and 1998, Africa had the lowest while Western Offshoots had the highest. In 1950 and 1973, Asia excluding Japan had the lowest while Western Offshoots had the highest.

Source: Maddison, Angus, The World Economy, A Millennial Perspective. OECD, 2001. Based on Table 3-1b, p. 126.

with growth acceleration in England due to the Industrial Revolution. Maddison disputes the interpretation and argues that 1820 is a much more crucial point separating periods of slow and rapid growth.

Third, Maddison is very critical of the widely held view developed by Paul Bairoch that China was well ahead of Western Europe in 1800 in terms of GDP per capita, that Japan and the rest of Asia were only 5 per cent lower than Europe, that Africa was one third lower and that Latin America was ahead of North America. Maddison finds that the relative income advantage of Western Europe was much greater. For example, while per capita GDP was higher in China than in Western Europe in 1000, it was significantly lower by 1500 and continued on a downward path, reaching 48.7 per cent in 1820 and a low of 


\section{Chart 3}

\section{Relative GDP Per Capita in China}

\section{Per cent of Total Western Europe}

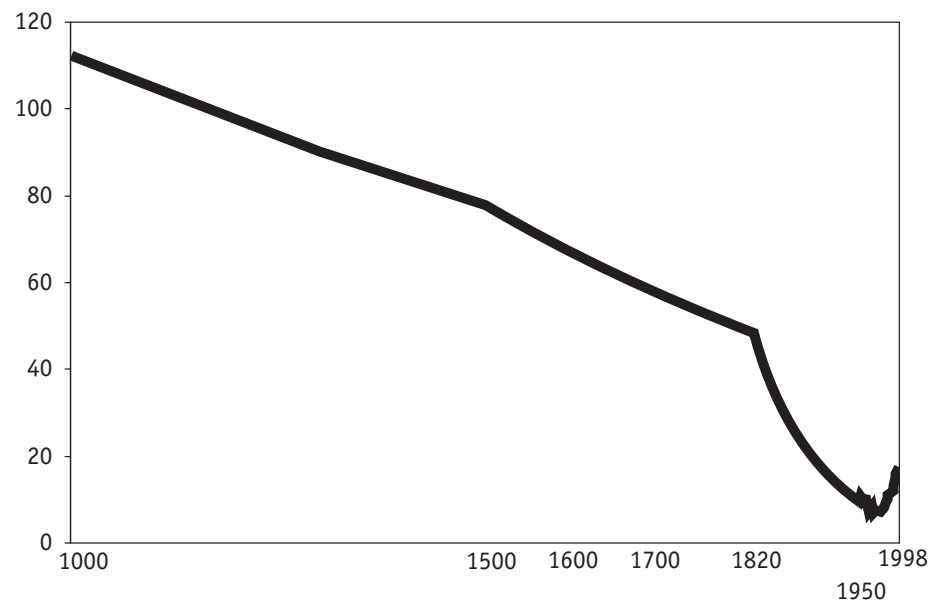

Note: Data are only available for 1000,1500,1600,1700,1820,1870,1913, and 1950 to 1998. Data for all other years are based on linear interpolation between the years for which data are available.

Source: Maddison, Angus, The World Economy, A Millennial Perspective. OECD, 2001. Based on Tables B-21, C1-C, and C3-C, p. 264, 278, and 304.

7.1 per cent of the Western European level in 1974 , before rebounding to 17.4 per cent in 1998. In absolute terms, Chinese economic performance (Chart 3) up to the mid-20th century has been abysmal, with per capita GDP in 1950 (\$439) lower than in 1000 (\$450). Equally, Maddison estimates that per capita GDP in Japan in 1820 was only 54.3 per cent of the Western European level, India 43.3 per cent, and Africa 21.2 per cent. Latin America in 1820 had 52.9 per cent of the GDP per capita of the United States.

\section{Perspectives on the Early Economic History of the Western Hemisphere}

Maddison provides a number of fascinating insights into the early economic history of North and South America, as the following three points illustrate.

- Canadians often use the rule of ten when comparing ourselves with the United States. Our population is about one tenth that of our southern neighbour as is the size of our GDP. Maddison shows that this rule applied even before the arrival of Europeans, suggesting that geography may be at the root of this constancy in Canada's relative population. In 1500, the aboriginal population of Canada was 250,000 , about one tenth the size of the U.S. population of 2 million.

- Only about 4 per cent (400 thousand) of the 9.4 million African slaves who were shipped to the western hemisphere from 1500 to 1870 went to the United States, with 40 per cent going to the Caribbean and 39 per cent going to Brazil. Yet the current population of over 30 million black Americans represent well more that 4 per cent of the total black population in the western hemisphere, suggesting mortality rates were much higher and fertility rates lower for slaves in the Caribbean and Latin America than in the United States.

- The collapse of the indigeneous population in Latin America after the arrival of the Spanish conquistadors is well know. Maddison shows that the collapse of the indigeneous population in the United States was equally dramatic. This population dropped from 2 million in 1500 to 750,000 in 1700 (still three-quarters of the U.S. population) to 325,000 in 1820 (only 3 per cent on the U.S. population), a fall of 88 per cent over three centuries.

\section{Per Capita GDP Estimates for Underdeveloped Countries}

Maddison's path-breaking quantification of the economic developments in the underdeveloped countries makes for depressing reading. $\mathrm{He}$ shows that with the exception of what he calls resurgent Asia (China, South Korea, Taiwan, Singapore, Hong Kong, Thailand, Malaysia and eight other somewhat less successful Asian countries), all regions of the underdeveloped world 
have experienced a much worse economic growth performance in the last quarter of the 20th century than in the third quarter (Chart 4). Growth in GDP per capita fell from an average annual rate of 4.1 per cent in the $1950-73$ period to 0.6 per cent in 1973-98 in other Asia, from 2.5 per cent to 1.0 per cent in Latin America, from 2.1 per cent to 0 in Africa, and from 3.5 per cent to -1.1 per cent in Eastern Europe and the former USSR. Only in resurgent Asia did growth pick up, from 2.6 per cent to 4.2 per cent. The importance of resurgent Asia is that it demonstrates that catch-up to the developed world is feasible for underdeveloped countries if the right conditions are present. It can be done.

Maddison provides annual estimates of GDP per capita for all countries in Latin America, Asia, and Africa from 1950 to 1998. The extent of the economic regress for many countries is astonishing as is the pace of economic advance for a small number of countries. In Latin America, GDP per capita declined in absolute terms in three out of 22 countries between 1950 and 1998. In Cuba GDP per capita fell 36.2 per cent from $\$ 3,390$ in 1950 to $\$ 2,164$ in 1998 , in Haiti 22.4 per cent over the same period from $\$ 1,051$ to $\$ 816$, and in Nicaragua 10.2 per cent from $\$ 1,616$ to $\$ 1,451$. The Latin American country that enjoyed the most rapid increase in living standards over the $1950-98$ period was Puerto Rico. Per capita GDP increased at a 3.9 per cent average annual rate from $\$ 2,144$ in 1950 to $\$ 13,253$ in 1998 , the highest level in Latin America. There were no other star performers in Latin America.

In Asia, four out of 56 countries experienced absolute declines in per capita GDP over the 1950-98 period. Surprisingly, the largest declines were experienced by two oil-producing countries, Qatar and Kuwait. Per capita GDP fell 76.1 per cent in the former from $\$ 30,510$ in 1950 to $\$ 7,304$ in 1998 and in the latter 60.9 per cent from $\$ 28,833$ to $\$ 11,273$. Rapid population

\section{Chart 4}

\section{Per Capita GDP in Less Developed Regions,} 1950-1973 and 1973-1998

Average Annual Growth Rates

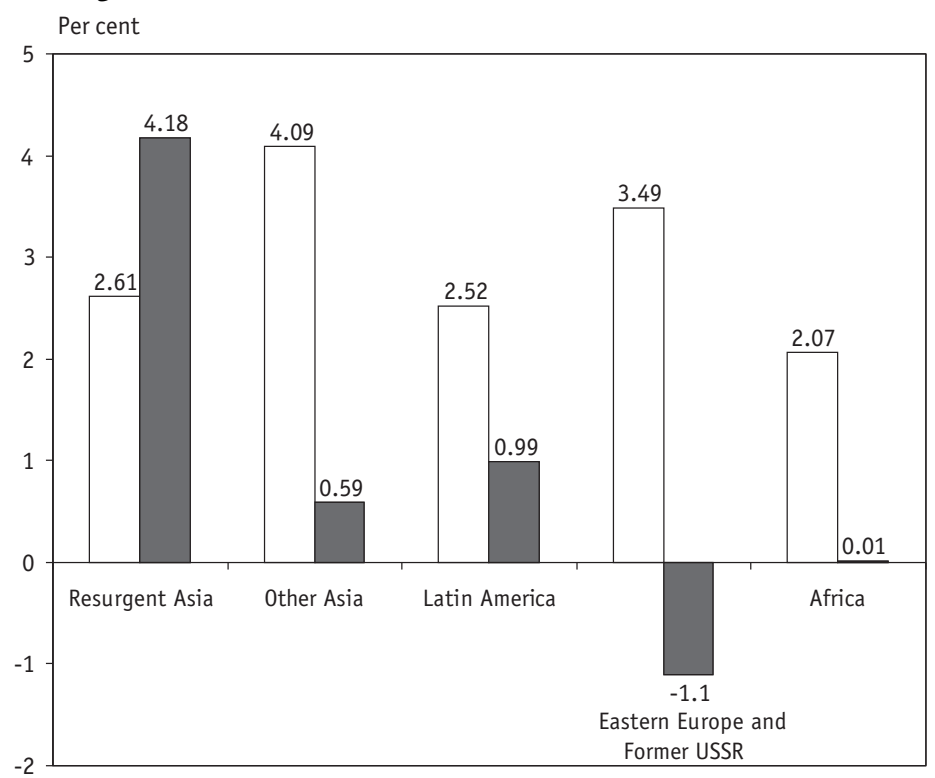

$1950-1973$

$1973-1998$

Source: Maddison, Angus, The World Economy, A Millennial Perspective. OECD, 2001. Based on Table 3-5, p. 129.

growth in these countries caused by in-migration attracted by the oil wealth accounts for the decline. Their absolute level of income is of course still high relative to other countries in the region. The other two countries that experienced declines were Iraq, with per capita GDP down 20.6 per cent from $\$ 1,364$ in 1950 to $\$ 1,131$ in 1998 (with a 44.5 per cent drop in 1991) and Afghanistan, down 20.3 per cent from $\$ 645$ to \$514. Indeed, Afghanistan in 1998 had the lowest per capita GDP in Asia and the second lowest in the world. Political turmoil has obviously contributed to the dismal economic performance of these two countries

The countries that have enjoyed the most rapid advances in living standards in the world over the last half century have been in Asia. Two countries tied for most rapid per capita GDP growth over the 1950-98 period, South Korea and Taiwan, each with average annual growth at 5.9 per cent per year. They were followed by 
Oman (5.3 per cent), Japan and Singapore (both at 5.0 per cent), and Hong Kong (4.7 per cent). It is particularly interesting to compare the economic performance of China and India. The former had per capita GDP growth over the 195098 period nearly double the latter (4.2 per cent per year versus 2.2 per cent).

The levels of GDP per capita attained by 1998 by the Asian super-achievers are extremely impressive. For example, Singapore's GDP per capita of \$22,643 in 1998 was the highest in Asia, even exceeding that of Japan $(\$ 20,410)$ and Hong Kong $(\$ 20,193)$. It was in fact the third highest in the world, exceeded only by Norway $(\$ 23,660)$ and the world leader, the United States $(\$ 27,331)$. GDP per capita in Canada was $\$ 20,559$.

The region with the worst economic performance in the second half of the 20th century has been Africa. Ten out of 57 African countries were worse off in terms of per capita GDP in 1998 than in 1950, when most of these countries were still colonies. The largest decline was in Angola at 38.5 per cent, followed by Niger (-34.6 per cent), Djibouti (-29.3 per cent), Madagascar (-27.4 per cent), Somalia (-16.5 per cent), Central African Republic (-15.4 per cent), Sierra Leone (-14.9 per cent), Liberia (-11.8 per cent), Comores (-6.8 per cent) and Chad (-1.1 per cent). This last country in 1998 had the lowest per capita GDP in the world at $\$ 471$.

Maddison finds that per capita GDP in Africa in $1998(\$ 1,368)$ was not much greater than the per capita GDP in Western Europe in 1820 $(\$ 1,232)$. In other words, the average African today is no better off that the average Western European nearly two hundred years ago. One factor behind this situation has been the corruption of African elites. Maddison points out that 40 per cent of African private wealth now consists of assets held abroad. This capital flight has had very negative consequences for Africa's economic development.

While Africa in general has been an economic disaster, the astounding economic perform- ance of one country should be pointed out. That country is Botswana, whose per capita GDP advanced at the extraordinary rate of 5.3 per cent per year from $\$ 349$ in 1950, the lowest in Africa, to $\$ 4,200$ in 1998 , the highest in Africa (excluding the relatively well off Indian Ocean islands of Reunion, Mauritius, and Seychelles which are included as part of Africa). No other African country had anywhere near as rapid growth. Indeed, of all the countries in the world, only two (Taiwan and South Korea) had faster per capita GDP growth over the period.

\section{Transition Economies}

It is well known that the developed world experienced slower productivity growth after 1973. But this slowdown pales in comparison to the productivity disaster that beset the Soviet Union and contributed to its collapse in 1991. Maddison attributes this situation to decreased micro-economic efficiency, an increased burden of military expenditure, depletion of natural resource advantages, and destruction caused by ecological horrors.

Maddison does produce estimates for these countries for the 1990-98 period and they paint a dismal picture. In the countries of the former Soviet Union, per capita GDP on average fell at an average annual rate of 6.9 per cent from 1990 to 1998. The largest decline was in Tajikistan (-14.9 per cent), followed by Georgia (-11.9 per cent), Moldova (-10.8 per cent), and Ukraine (-10.2 per cent). The best performance was by Estonia, with per capita GDP only falling 0.7 per cent per year over the period. The economic debacle lead to a massive deterioration in living standards. For example, the proportion of the population in poverty in Ukraine skyrocketed from 2 per cent in 1987-88 to 63 per cent in 1993-95.

Economic decline in Eastern Europe was much less drastic than in the USSR, with per capi- 
ta GDP actually rising 0.1 per cent per year from 1990 to 1998. The worst performance was experienced by the former Yugoslavia (-3.5 per cent per year), followed by Romania ( -2.5 per cent) and Albania (-2.4 per cent). The economic success story was without a doubt Poland, with per capita GDP growing at a very impressive 3.4 per cent average annual rate. Slovenia followed far behind with per capita GDP growth of 1.1 per cent.

\section{New Perspectives on Canada's Relative Economic Performance.}

Maddison's estimates of per capita GDP provide new perspectives on Canada's relative economic performance, questioning conventional wisdom in two ways. First, his data cast doubt on the widespread view that Canada's international ranking in terms of GDP per capita has deteriorated over the last half century. In 1950, Canada's per capita GDP at $\$ 7,437$ was the fifth highest in the developed world, exceeded only by that of the United States $(\$ 9,561)$, Switzerland $(\$ 9,064)$, New Zealand $(\$ 8,453)$, and Australia $(\$ 7,493)$. By 1998 at $\$ 20,559$ Canada still had the sixth highest GDP per capita in the world, now exceeded by only that in the United States $(\$ 27,331)$, Norway $(\$ 23,660)$, Singapore $(\$ 22,643)$, Denmark $(\$ 22,123)$, and Switzerland $(\$ 21,367)$. In 1950, Canada had the second highest GDP per capita among G7 countries. This was still the case in 1998 .

Second, Maddison shows that Canadian income and productivity levels have not converged to U.S. levels, as is commonly believed. Rather, since the early part of the 20th century, they have actually fallen relative to those in the United States. Chart 5 shows trends in GDP per capita in the two countries from 1820 to 1998 based on data for 1820,1870, 1913, and for all years from 1950 to 1998 and Chart 6 shows trends in Canada's per capita GDP as a percentage of the

\section{Chart 5}

\section{Real GDP per Capita in Canada and the United States, 1820-1998}

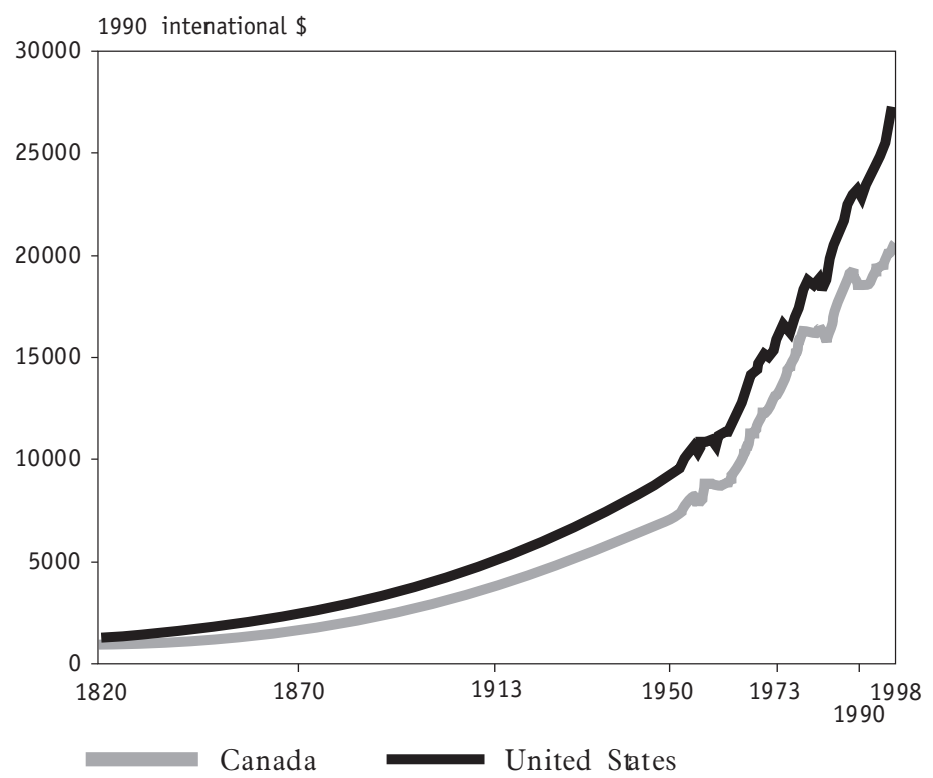

Note: Data are only available for 1820,1870, 1913, and 1950 to 1998. Data for all other years are based on linear interpolation between the years for which data are available.

Source: Maddison, Angus, The World Economy, A Millennial Perspective. OECD, 2001. Based on Tables A1-c, p. 185 and C1-c, p. 279.

U.S. level over the period. From 69 per cent of the U.S. level of per capita GDP in 1870, Canada advanced to 84 per cent in 1913 reflecting more rapid GDP per capita growth during the 18701913 period. From 1913 to 1950 Canada experienced a decline in relative per capita GDP, falling to 78 per cent of the U.S. level in 1950. Convergence toward U.S. levels did take place in the 1950-73 period, but since 1973 Canada's relative per capita GDP has again deteriorated, falling to 75 per cent of the U.S. level in 1998, a level originally achieved around 1900.

Canada's relative productivity performance has mirrored its income performance. Chart 7 shows the level of GDP per person employed in Canada and the United States for 1820, 1870, 1913, 1950, 1973, 1990, and 1998. Chart 8 indicates the level of GDP per hour worked for the same years. Chart 9 gives Canada's GDP per person employed and hour worked as a percentage of that in the 


\section{Chart 6}

\section{Real GDP per Capita, Canada as a Percentage of the United States, 1820-1998}

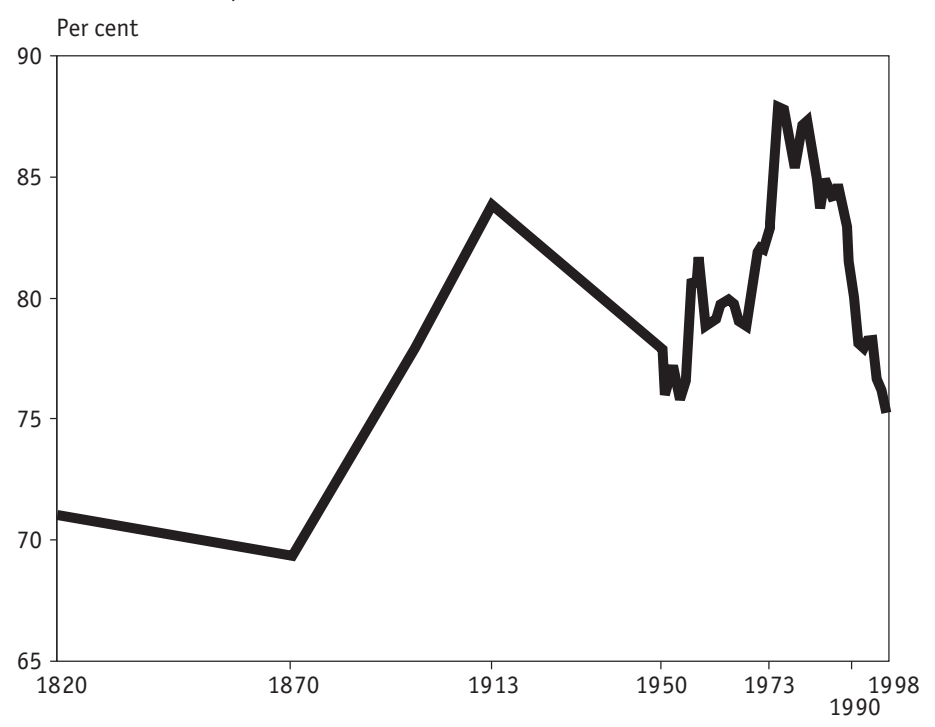

Note: Data are only available for 1820,1870, 1913, and 1950 to 1998. Data for all other years are based on linear interpolation between the years for which data are available.

Source: Maddison, Angus, The World Economy, A Millennial Perspective. OECD, 2001. Based on Tables A1-c, p. 185 and C1-c, p. 279.

\section{Chart 7}

\section{Real GDP per Person Employed, Canada and the United States, 1870-1998}

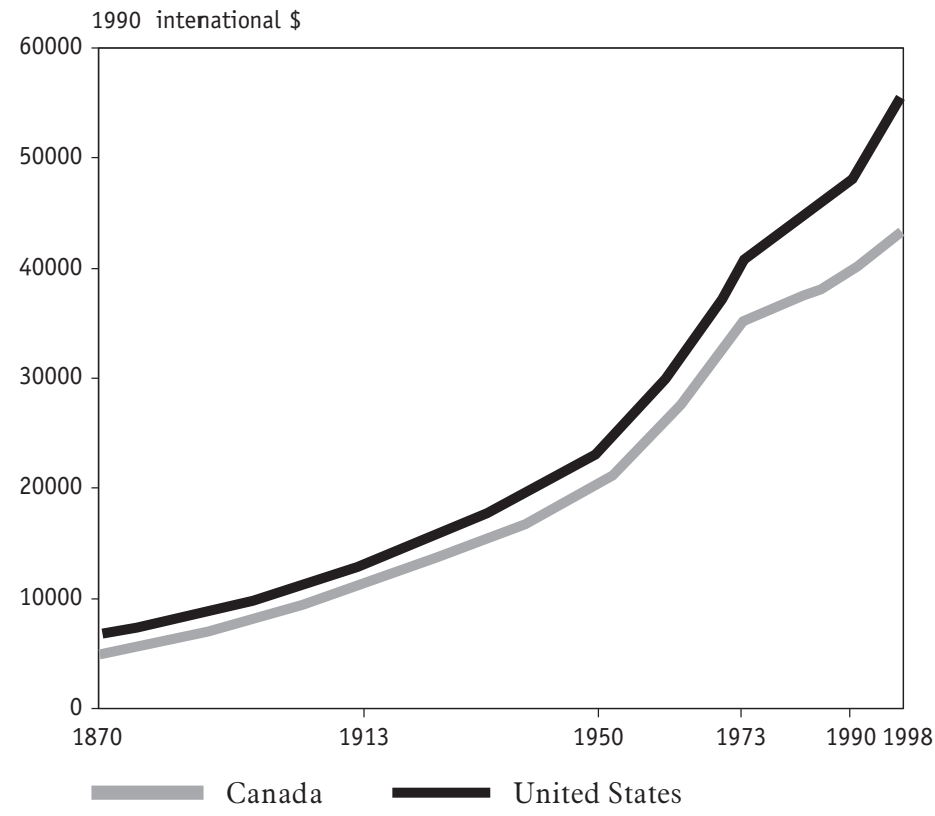

Note: Data are only available for 1870, 1913, 1950, 1973, 1990, and 1998. Data for all other years are based on linear interpolation between the years for which data are available.

Source: Maddison, Angus, The World Economy, A Millennial Perspective. OECD, 2001. Based on Table E-5, p. 349.
United States. Canada's output per hour gap narrowed from 76 per cent of the U.S. level in 1870 to 87 per cent in 1913 , then widened to 82 per cent in 1950 , narrowed slightly to 83 per cent in 1973 , and then widened again to 78 per cent in 1990 and 75 per cent in 1998. In other words, Canada's aggregate level of output per hour, relative to that in the United States, was lower in 1998 than in 1870 , indicating no convergence toward the higher U.S. level in the past 130 years.

However, caution is warranted regarding these statistics. This lack of convergence between Canadian and U.S. income and productivity levels may not be a real phenomenon because of measurement problems. Unrelated to the issue of the Canada-U.S. income gap, Maddison notes that two very important developments in national accounting in recent years have been the replacement of the Lasperyesfixed weighted index by the Fisher-chain index and the use of price indices based on hedonics. Maddison expresses reservations about the use of both methodologies for long-term economic history. He notes that because of these changes U.S. GDP growth for the 1929-50 period has been boosted from 2.6 per cent per year to 3.5 per cent. This results in lower productivity levels in earlier years as these levels must be consistent with current levels and growth rates. He notes that the United States is the only country that revises its historical series back many decades incorporating these new methodologies and he questions this practice. For example, Canada has preserved historical growth rates in its real GDP series for the pre-1961 period despite changes in methodology.

Thus the lower GDP per capita gap between Canada and the United States in 1913 than in 1998 may just be a reflection of the fact that the United States revised its real GDP series back much earlier than Canada. This situation highlights the problems of the international comparability of GDP estimates when methodologies differ across 
countries. More work is needed before a definitive conclusion can be drawn on whether income and productivity levels in Canada converged toward the U.S. level during the 20th century.

\section{Relevance to Current Policy-making}

Current policy making should be informed both from history and from contemporary international experience. Maddison documents and explains a large number of historical developments that hold great relevance for contemporary policy makers.

Maddison provides a number of insights into the drivers of economic growth that have relevance today. For example, he notes that even in 1776 the United States had nine universities for its 2.5 million people, compared to two in all of Latin America (both in Mexico and none in Brazil, both countries with larger populations than the United States at the time). This historical advantage in human capital development, linked to the importance accorded education by early European settlers in British North America, particularly in northern colonies such as New England, has served and continues to serve the United States well. In contrast, Latin America's relatively underdeveloped education sector, especially higher education, has not fostered economic development.

The Netherlands emerges as a success story in Maddison's history of the world economy. As already noted, it had the highest income level in the world for nearly three centuries from 1564 to 1836. More recently, it has been able to maintain a low unemployment rate and low inflation. Maddison notes that solidaristic attitudes among the Dutch population, which for example have allowed the country to pursue an effective incomes policy, have been responsible for the recent success. The roots of these attitudes have a long history in Dutch society, going back many

\section{Chart 8}

\section{Real GDP per Hour, Canada and the United States, 1870-1998}

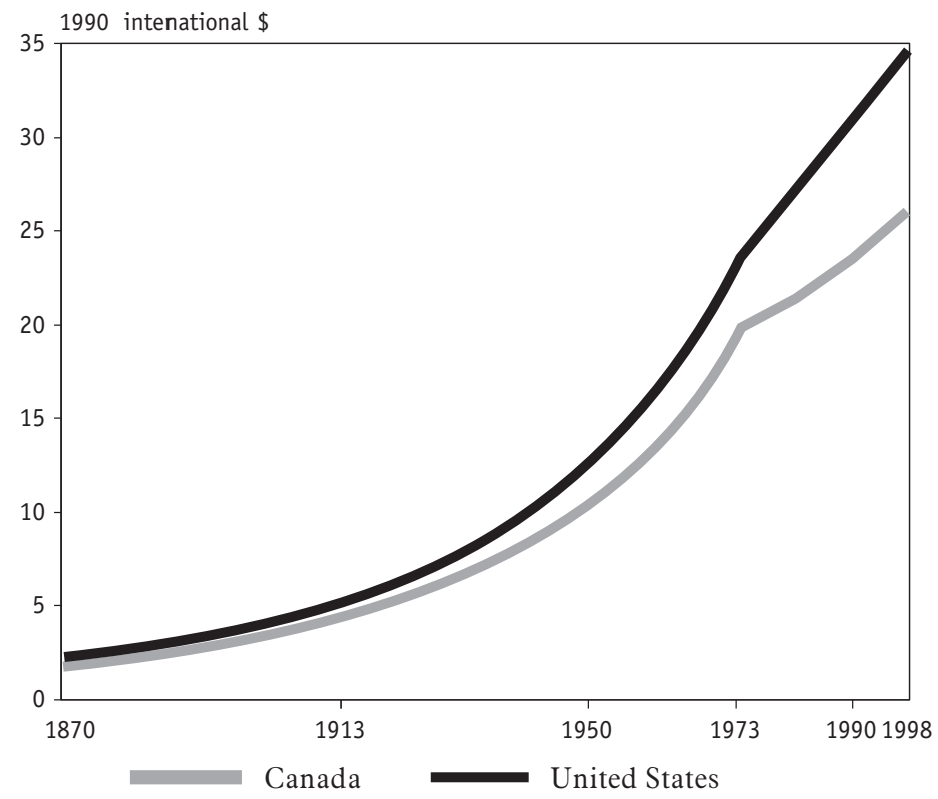

Note: Data are only available for 1870,1913, 1950, 1973, 1990, and 1998. Data for all other years are based on linear interpolation between the years for which data are available.

Source: Maddison, Angus, The World Economy, A Millennial Perspective. OECD, 2001. Based on Table E-7, p. 351.

\section{Chart 9}

\section{Labour Productivity, Canada as a Percentage of the United States, 1870-1998}

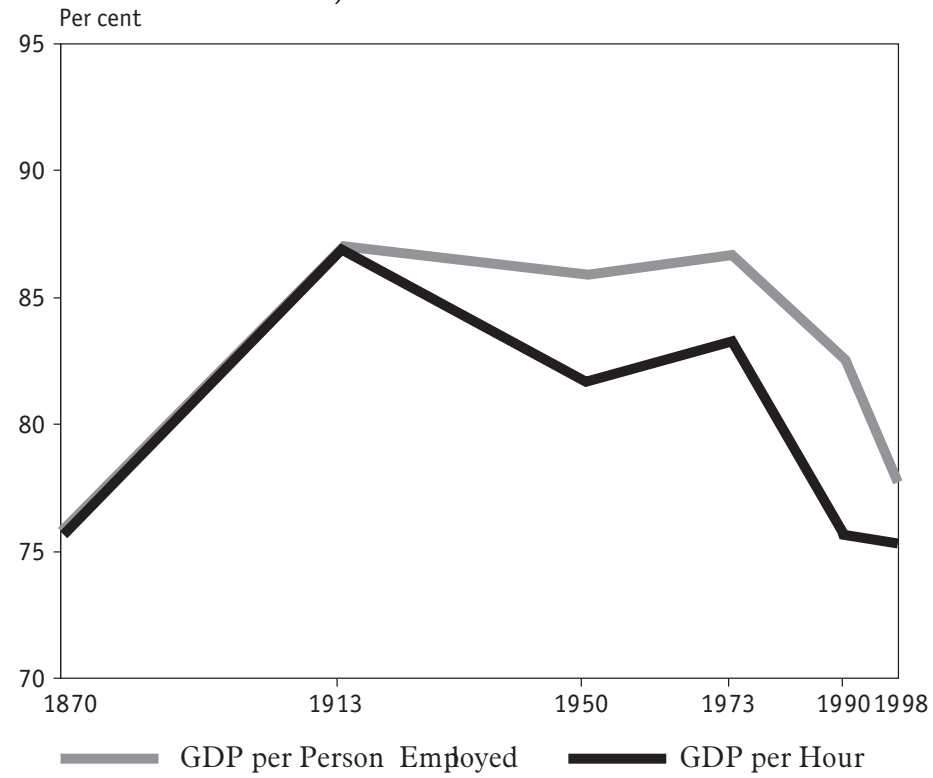

Note: Data are only available for 1870, 1913, 1950, 1973, 1990, and 1998. Data for all other years are based on linear interpolation between the years for which data are available.

Source: Maddison, Angus, The World Economy, A Millennial Perspective. Based on Tables E-5, E-7, p. 349, 351. 
centuries to the reliance on control of water through the system of dikes. This suggests that solidaristic attitudes are generated though historical circumstances and cannot develop overnight.

Maddison believes that technical progress is the driver of economic growth and that it can be proxied by total factor productivity growth. $\mathrm{He}$ believes that the pace of technological advance has been substantially faster in the 20th century than in the 19th century. He also feels that the post1973 slowdown in productivity growth is evidence of a deceleration in technical progress. He is skeptical about whether the post-1995 revival in productivity growth in the United States represents a permanent revival in productivity to the pace of the postwar golden age (1945-73).

Regional income disparities are a matter of concern in Canada and regional development policies have attempted to reduce them. Maddison provides international perspective on this phenomenon, noting that these disparities can be much greater in underdeveloped countries than in developed countries. For example, he notes that the ratio of the income of the richest region to that of the poorest in Brazil is 7:1. Mexico and China also have very large regional income differences. In contrast, in Canada, the ratio in terms of GDP per capita between the richest and poorest province (Alberta and Newfoundland) in 1999 was 1.8:1.

Maddison points out that the most disturbing aspect of Western European economic performance since 1973 has been the staggering rise in unemployment. He believes that the major reason for this development has been the change in macro-policy objectives. Initially, this was dictated by events, but Maddison believes its continuation reflected a basic ideological shift, namely the jettisoning in the 1970s of the objective of full employment and rapid economic growth and a focus on price stability. Maddison also blames monetary union for the persistence of deflationary policies in the 1990s. Maddison's critique of
Western European macroeconomic policies is refreshing, especially coming from someone so long associated with the OECD, a purveyor of economic orthodoxy. A more developed critique of these policies would have been useful, although it is somewhat peripheral to the main thrust of the volume. Maddison should be encouraged to tackle this topic in a more thorough manner in the future.

\section{Conclusion}

The World Economy: A Millennial Perspective is a tour de force. It will be required reading for all economists interested in long-run economic growth trends. The massive number of new estimates of population, GDP and per capita GDP for long periods for virtually all countries of the world presented in the volume represent a major contribution to the world's knowledge base. By no means definitive, they will stimulate debate for years to come. Angus Maddison is to be congratulated for producing this path-breaking work.

\section{Notes}

1 Published by the Development Centre of the OECD in 2001. Can be ordered for $\$ 35.00$ U.S. from the OECD bookroom online at www.oecd.org.

2 Through this article, growth in per capita GDP is measured in real terms, with per capita GDP levels expressed in terms of 1990 U.S. international dollars based on purchasing power parities.

3 Annual GDP estimates in 1990 international dollars for earlier periods for many countries can be obtained by linking the series in this volume to those published in Maddison's earlier work Monitoring the World Economy, 1920-1992 (OECD Develpment Centre, 1995). 